\title{
The Evaluation and Improvement of Performance in China Companies' Mineral Resources-obtaining International Strategic Alliances: a Perspective of Value Creation
}

\author{
Si-Yu Pan ${ }^{1, a}$, Kai-Ting Chen ${ }^{2, b}$ \\ ${ }^{1,2}$ Business School, Guangxi University, Nanning 530003, China \\ apsy2003@126.com, ${ }^{\mathrm{b}} \mathrm{ckt7825887@163.com}$
}

\begin{abstract}
Keywords: China companies, Mineral Resources-obtaining, International strategic alliance, Performance evaluation, Performance improvement.
\end{abstract}

\begin{abstract}
This paper analyses the generating mechanism of China Companies' mineral resources-obtaining international strategic alliances (MROISA) performance from the perspective of value creation, and builds an evaluation index system of China Companies' MROISA performance from two aspects of the expected performance and non-expected performance. Based on the evaluation index system, this paper points out that the improving tactics of China Companies' MROISA expected performance are to strengthen the qualities and quantities of mineral resources inputted by alliance partners, reduce the risks from politics, culture, information, technology, funds and management, decrease the costs in system, facilities construction, exploration and development, environmental protection and transport; the improving tactics of non-expected performance are to accelerate inventory turnover and current assets turnover, raise mineral resources utilization rate and product qualification rate, increase market share and enhance market power.
\end{abstract}

\section{Introduction}

With the increasingly deepening development of economic globalization and regional economic integration, China Companies' mineral resources-obtaining international strategic alliances (MROISA) have been the mainstream competition pattern of China Companies to obtain foreign mineral resources. Nowadays, China Companies' MROISA have achieved initial results, but their overall performances are not ideal. Investigation shows that, one of the major reasons is that the value creation of China Companies' MROISA is insufficient.

At present, there are few direct researches on the evaluation and improvement of China Companies' MROISA performance, but many researches about the evaluation and improvement of strategic alliance performance. (1) Scholars generally established multidimensional index system to evaluate alliance performance. Glaister \& Buckley (1998) [1] synthetically used both subjective and objective indexes, such as satisfied degree, the ratio of alliance earning to alliance cost, stability and duration etc. Nielsen (2007) [2] constructed the alliance performance evaluating model from four dimensions: relational equality, financial performance, learning and alliance target reaching. Mohr (2006) [3] argued that technology alliance performance included five dimensions: technical knowledge acquisition, alliance earning, alliance member growth, alliance market share and alliance stability. Gang Xiang (2012) [4] constructed the evaluation index system of technology innovation strategy alliance performance from both process and output aspects. Hui Ren (2011) [5] advised that the evaluation dimensions of knowledge alliance performance included knowledge creation results and alliance cooperation process. Shuling Shi (2011) [6] respectively measured individual alliance performance and overall alliance performance of knowledge alliance based on different purposes of appraising subject. (2) Different theories held different views on the improving tactics of alliance performance. Transaction cost theory considered both alliance sides could decrease transaction cost and enhance alliance performance through selecting effective alliance governance (Mohr \& Spekman, 1994; Sampson, 2004; Yanfeng Zhang etc., 2007; Jianying Liang, 2010; Jian Li etc., 2007) [7-11]. Resource based theory emphasized resource complementarity between both alliance sides could effectively enhance alliance performance (Lusch \& Brown, 1996; Dyer \& Singh, 1998; 
Holm etc., 1999) [12-14]. Competence theory argued alliance performance could be improved through building and enhancing alliance capability (Simonin, 1997; Kale etc., 2002; Shenghua Zheng etc., 2007) [15-17].

Based on the rational kernels of the above researches, this paper researches the evaluation and improvement of performance in China Companies' MROISA from the perspective of value creation, hoping to provide theoretical support and decision-making reference for China Companies to further develop foreign market, improve international competitiveness and obtain sustainable competitive advantage.

\section{The Performance of China Companies' MROISA}

\section{The Definition and Motivations of China Companies' MROISA}

The Definition of China Companies' MROISA. China Companies' MROISA is, in order to obtain foreign mineral resources, a combined union constructed by China Companies and foreign companies owning mineral resources through equity or contract to share advantages, benefits and risks on the strategic level. According to value chain theory, China Companies' MROISA can be divided into two forms: (1) vertical alliance: both alliance sides cooperate in the production-marketing of mineral resources; (2) horizontal alliance: both alliance sides cooperate in the development of mineral resources. This paper just researches the horizontal alliance because it has a big proportion in China Companies' MROISA shown from practice. And in the horizontal alliance, according to the application of mineral resources obtained, China Companies can be subdivided into two categories. The first sell the mineral resources obtained directly, and the second make the mineral resources obtained as raw materials and process them into products for sale. This paper just researches the latter because it accounts for a large percentage in China Companies' horizontal MROISA shown from practice.

The Motivations of China Companies' MROISA. Various alliance demands result in corresponding alliance motivations. According to China Companies' demands of foreign mineral resources, the motivations of China Companies' MROISA include three aspects: (1) obtain foreign mineral resources by developing them with alliance partners directly; (2) reduce foreign mineral resources-obtaining risk by using alliance partners' local knowledge resources and relationship resources to minimize the influence of uncertain factors for alliance formation and operation; (3) save foreign mineral resources-obtaining cost by making internal transaction in alliance and expanding the organizational boundary of obtaining resources.

\section{The Definition and Generating Mechanism of China Companies' MROISA Performance}

The Definition of China Companies' MROISA Performance. Performance usually refers to the achievement of people engaging in a certain activity. China Companies' MROISA performance is the effect of establishing and operating MROISA, and the index reflecting alliance value creation results.

The Generating Mechanism of China Companies' MROISA Performance. China Companies' MROISA are established to achieve alliance demand (expected demand). In accordance with alliance demand, both alliance sides invest special assets or proprietary core resources in alliance, and then it makes MROISA produce alliance utility (expected utility) through operating alliance. According to western economics theory, only when alliance utility matching alliance demand can create value (expected value) [18], and acquire corresponding alliance performance (expected performance). Afterwards, China Companies use the expected performance obtained to promote enterprise demand (non-expected demand) and get enterprise utility (non-expected utility) through operating enterprise. By the same token, only when enterprise utility matching enterprise demand can create value (non-expected value), and acquire corresponding enterprise performance (non-expected performance) which is motivated by expected performance obtained. In general, for both expected and non-expected aspects, the greater utilities match demands, the more values are created, and the higher performances are acquired. Usually, both alliance sides evaluate the size of alliance value creation and alliance performance through the satisfied degree of their alliance demands. It's usually a subjective evaluation based on an objective judgment (such as cost saving or 
income increasing brought from alliance), and it generally refers to enterprise managers' subjective satisfied degree. Both alliance sides have different alliance demands or the satisfied degrees of alliance demand, and it results in their different evaluations of alliance value creation and alliance performance. [18] In general, the generating mechanism of China Companies' MROISA performance is shown in Fig.1.

Expected performance is the China Companies' alliance expected demand satisfied and implemented through MROISA, and also the expected goal achieved by operating MROISA. Non-expected performance is the China Companies' alliance non-expected demand, which propelled by China Companies' expected performance obtained, satisfied and implemented through operating enterprise, and also the non-expected goal established on the basis of expected performance. In China Companies' MROISA, expected performance may cause non-expected performance. Because expected performance is produced in upstream process (raw material) of China Companies' value chain, and it's necessary for China Companies to use it to drive the downstream process (including inventory, production, marketing etc.). Generally, the higher expected performance, the greater the driving force of it to propel the downstream demand of enterprise, and it's more likely to create non-expected value and acquire non-expected performance. But expected performance cannot cause non-expected performance absolutely. Because there is a competitive and cooperative relationship between both alliance sides, but if they pay overmuch attention to competition and neglect cooperation, it may lead to few expected performances for China Companies, which would be difficult to form the sufficient driving force to non-expected performance. Thus, China Companies' MROISA non-expected performance is based on expected performance and dynamically driven by it; in other words, China Companies' MROISA performance is a dynamic combination of the expected performance and non-expected performance.

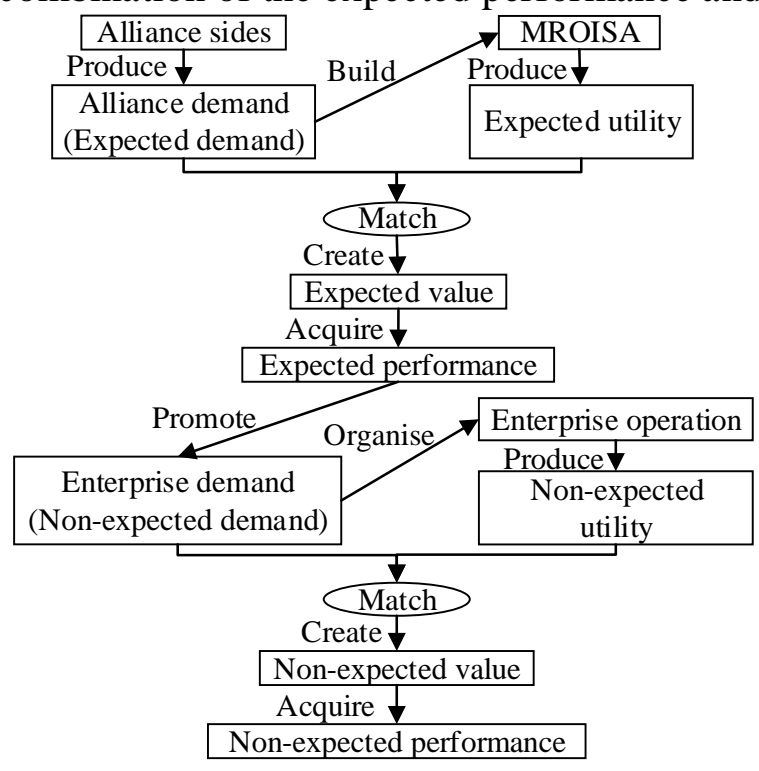

Fig.1 The generating mechanism of China Companies’ MROISA performance

\section{The Evaluation of China Companies' MROISA Performance}

\section{Evaluation Object and Thinking}

There are two evaluation levels of MROISA performance: whole level and individual level. The evaluation object of this paper focuses on the individual level, and evaluates the performance that China Companies can obtain from MROISA.

The specific thinking of China Companies' MROISA performance evaluation includes two parts. (1) The Evaluation Angle. According to comprehensive performance evaluation theory, we build an evaluation index system of China Companies' MROISA performance from two aspects: expected performance reflecting the satisfied and realized degree of expected demand, and non-expected performance reflecting the additional gain based on expected performance obtained. Afterwards, we measure the expected performance and non-expected performance in different ways. On one hand, 
we measure expected performance by the satisfied degree of China Companies' expected demand. In order to measure the satisfied degree of expected demand accurately, we decompose China Companies' expected demand into several sub-demands, and design each evaluation dimension of expected performance according to each sub-demand. On the other hand, we use value chain theory to measure non-expected performance because non-expected performance is the extra income which is brought from the operation of China Companies' internal value activities associated with expected performance obtained. Inventory, production and marketing can be propelled by expected performance obtained obviously in China Companies' internal value activities, so the evaluation dimensions of non-expected performance should include inventory, production and marketing. (2) The Index Design. The evaluation indexes are designed from two aspects of the expected performance and non-expected performance. To ensure the comprehensiveness, diversity and scientificity of indexes, the expected performance evaluation indexes are selected according to expected demand, and the non-expected performance evaluation indexes are chosen according to the requirements of inventory, production and marketing.

\section{Evaluation Index System}

Tab. 1 The evaluation index system of China Companies' MROISA performance

\begin{tabular}{|c|c|c|c|c|}
\hline $\begin{array}{l}\text { Target } \\
\text { layer }\end{array}$ & $\begin{array}{l}\text { First } \\
\text {-class }\end{array}$ & $\begin{array}{l}\text { Second } \\
\text {-class }\end{array}$ & Third-class & Description of third-class index \\
\hline \multirow{5}{*}{ 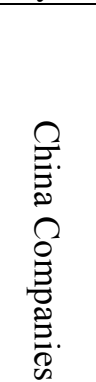 } & \multirow{13}{*}{ 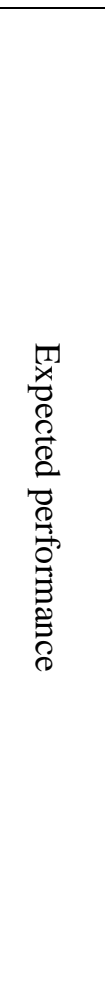 } & \multirow{2}{*}{$\begin{array}{l}\text { Mineral } \\
\text { resources }\end{array}$} & Reserves & $\begin{array}{l}\text { Recoverable reserves, pre-recoverable } \\
\text { reserves }\end{array}$ \\
\hline & & & Grade & Average grade \\
\hline & & \multirow{6}{*}{ Risk } & Political risk & $\begin{array}{l}\text { War risk, policy and law risk, diplomatic } \\
\text { relation risk }\end{array}$ \\
\hline & & & Cultural risk & $\begin{array}{l}\text { Cultural conflict risk, customs and } \\
\text { religious conflict risk }\end{array}$ \\
\hline & & & Information risk & $\begin{array}{l}\text { Information integrity and accuracy risk, } \\
\text { mineral resources calculation standard risk }\end{array}$ \\
\hline \multirow{2}{*}{ 龸. } & & & Technique risk & $\begin{array}{l}\text { Exploration risk, exploitation risk, } \\
\text { beneficiation risk, technology leakage risk }\end{array}$ \\
\hline & & & Capital risk & Financing risk, working capital risk \\
\hline $\begin{array}{l}\overrightarrow{0} \\
\overrightarrow{0} \\
\infty\end{array}$ & & & Management risk & $\begin{array}{l}\text { Natural disaster risk, human resources } \\
\text { risk, environmental risk }\end{array}$ \\
\hline $\begin{array}{l}E \\
0 \\
\infty \\
\infty \\
1\end{array}$ & & \multirow{5}{*}{ Cost } & System cost & $\begin{array}{l}\text { Exploration license-obtaining cost, } \\
\text { exploitation license-obtaining cost }\end{array}$ \\
\hline 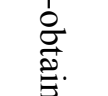 & & & $\begin{array}{l}\text { Facilities } \\
\text { construction cost }\end{array}$ & $\begin{array}{l}\text { Essential facilities construction cost, } \\
\text { auxiliary facilities construction cost }\end{array}$ \\
\hline \multirow{6}{*}{ 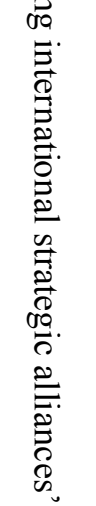 } & & & $\begin{array}{l}\text { Exploration and } \\
\text { development cost }\end{array}$ & $\begin{array}{l}\text { Exploration cost, exploitation cost, } \\
\text { beneficiation cost }\end{array}$ \\
\hline & & & Environmental cost & $\begin{array}{l}\text { Environmental facilities investment, waste } \\
\text { recycling fee, pollutant treatment fee }\end{array}$ \\
\hline & & & Transport cost & $\begin{array}{l}\text { Tangible transport cost, intangible } \\
\text { transport cost }\end{array}$ \\
\hline & \multirow{6}{*}{ 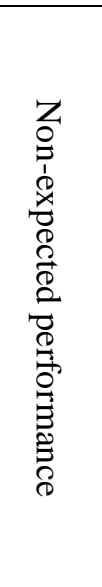 } & \multirow[b]{2}{*}{ Inventory } & Inventory turnover & Raw material turnover, product turnover \\
\hline & & & $\begin{array}{l}\text { Current assets } \\
\text { turnover }\end{array}$ & $\begin{array}{l}\text { The ratio of main business net income to } \\
\text { average total current assets }\end{array}$ \\
\hline & & \multirow{2}{*}{ Production } & $\begin{array}{l}\text { Mineral resources } \\
\text { utilization rate }\end{array}$ & $\begin{array}{l}\text { The ratio of mineral resources available } \\
\text { quantity to mineral resources-obtaining } \\
\text { amount }\end{array}$ \\
\hline \multirow{3}{*}{ 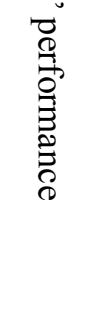 } & & & $\begin{array}{l}\text { Product qualification } \\
\text { rate }\end{array}$ & $\begin{array}{l}\text { The ratio of the number of qualified } \\
\text { products to the total products }\end{array}$ \\
\hline & & \multirow{2}{*}{ Marketing } & Market share & $\begin{array}{l}\text { The ratio of enterprise sales amount } \\
\text { (quantity) to market sales amount } \\
\text { (quantity) }\end{array}$ \\
\hline & & & Market force & $\begin{array}{l}\text { The influence of the supply guarantee of } \\
\text { mineral resources, the influence of } \\
\text { product }\end{array}$ \\
\hline
\end{tabular}


At first, we design the evaluation indexes of expected performance and non-expected performance following the above evaluation object and thinking. Then, according to the actual situation of China Companies' MROISA, we consult experts about designing and selecting indexes through questionnaire survey. Finally, after repeated trial and modification, we confirm the evaluation index system of China Companies' MROISA performance shown in Table.1.

\section{Evaluation Methods}

The evaluation methods of China Companies' MROISA performance contain the assignment method and weighting method. Firstly, we choose fuzzy comprehensive evaluation (FCE) to assign the evaluation indexes. Because there are many evaluation indexes are difficult to quantify in table 1 , and FCE can solve the problem effectively through using membership degree in fuzzy mathematics to translate qualitative evaluation into quantitative evaluation. Secondly, we elect analytic hierarchy process (AHP) to determine the weight of evaluation indexes for three reasons: (1) it can be used in conjunction with FCE due to its strong compatibility; (2) it has a strict mathematical foundation due to its consistency test and normalization; (3) its calculation is easy to operate.

\section{Evaluation Result Analysis}

Through the calculation of FCE and AHP, each evaluation index gets its weighted coefficient and score. Then we calculate the numerical value of China Companies' MROISA performance by Eq. 1.

$$
c=\sum a \times b
$$

In Eq. 1, c represents the numerical value of China Companies' MROISA performance, a represents the weighted coefficient of each evaluation index, and b represents the score of each evaluation index.

According to the numerical value of China Companies' MROISA performance, and referring to the standard values and grades of companies performance evaluation made by financial supervision and appraisal agency of state-owned assets supervision and administration commission of the state council in 2014, China Companies' MROISA performance can be divided into 5 grades: very poor, poor, average, good, excellent, and the corresponding numerical ranges of 5 grades are $0 \sim 39,40 \sim$ $59,60 \sim 79,80 \sim 89,90 \sim 100$. Seen from the relationship of alliance performance to alliance success, these 5 grades respectively represent 5 success levels of China Companies' MROISA: failure, unsuccessfulness, mixed success, general success and success.

\section{The Improving Tactics of China Companies' MROISA Performance}

\section{The Improving tactics of Expected Performance}

Strengthen the Qualities and Quantities of Mineral Resources Inputted by Alliance Partners. First of all, choose companies with great reserves as alliance partners, and then take effective measures to persuade alliance partners to increase resource commitment quantity. Because a number of reserves possessed and invested by alliance partners usually decide how many mineral resources China Companies can obtain from MROISA.

Secondly, set a suitable grade requirement of mineral resources. In many cases, it's difficult for companies to strike a balance between reserves and high-grade. But the grade requirement of mineral resources can be determined by the companies' specific requirement of mineral resources: if China Companies focus more on the quantity of mineral resources, the grade requirement can be appropriately reduced; if China Companies pay more attention to the quality of mineral resources, the grade requirement can be moderately improved.

Reduce Risks. Firstly, reduce political risk. When selecting alliance partners, China Companies should take into full account the political stability and economic conditions of the host country. The stable and prosperous macro environment is important to the establishment and operation of 
MROISA. If meeting the prerequisite, China Companies can further consider choosing alliance partners coming from the host country which be on good diplomatic relations with our country. With the help of a diplomatic advantage, MROISA can be established and operated more smoothly. And a professional lawyer team can be employed to settle the legal problem of MROISA.

Secondly, reduce cultural risk. To strengthen cultural exchange between both alliance sides, China Companies should learn the social culture of the host country and spread Chinese culture initiatively. And to maintain alliance stability, China Companies should respect the local customs and religious when formulating alliance management regime.

Thirdly, reduce information risk. (1) Assure the integrity and accuracy of information. In the stage of information collection, China Companies can use a two-pronged approach: both alliance sides take joint actions to get as much related information as possible. Then in the stage of information verification, China Companies should carefully verify all information, giving priority to own analysis and demonstration and taking alliance partners' suggestion as a reference. If necessary, China Companies can hire professionals to validate related information to ensure information accuracy. (2) Set a suitable calculation standard of mineral resources. Different countries might have different calculation standards of mineral resources. China Companies should seriously inspect the project contents, including calculation method, the selection and setting of parameter etc., to ensure they are scientific, reasonable, and meet the Chinese calculation standard as well.

Fourthly, reduce technique risk. In order to effectively deal with technical problem occurred in the development of mineral resources, both alliance sides ought to establish professional teams with rich experience in exploration, exploitation and beneficiation. In these teams, technical support can be provided by China Companies, and the experience of developing local mining area can be provided by alliance partners. If necessary, China Companies can consider researching or introducing new technology with alliance partners. With the collective power of both alliance sides, the possibility of breaking through technical bottleneck can be increased. Importantly, China Companies should set the bound of technology sharing and security. It means that China Companies can exchange non-core technology for alliance partners' technology, which will help to strengthen the trust and communication between both alliance sides through technology sharing; and formulate core technology secrecy regime, which should particularly point out the scope and rank of core technology secrets, and sign a confidentiality agreement with staff to prevent them from leaking core technology in technical communications.

Fifthly, reduce capital risk. Both alliance sides take joint actions to expand alliance fundraising channels: alliance partners can raise money in the host country, and China Companies can do it in the non-host country. And financing objects include government, enterprise, bank, trade association, commercial organization etc.; financing ways include fiscal financing, credit financing, capital market financing, commercial financing etc. At the same time, the risk prevention and management mechanism should be built to analysis, evaluate and control the financing risk and working capital risk.

Sixthly, reduce management risk. (1) Guard against natural disaster. China Companies can know usual natural disaster in the mining area through alliance partners, then construct the natural disaster monitoring and early warning system and formulate contingency plan and preventive measure. (2) Strengthen human resources management. When setting up positions, China Companies should adhere to the principle of "positions based on business, people and positions matching" to avoid overstaffed and inefficient organization. Afterwards, China Companies can establish effective communication mechanism to promote lateral and vertical communication between both alliance sides, and properly handle the relationship of competition to cooperation between both alliance sides because full cooperation helps to promote employee's unity and moderate competition is good for improving employee's working efficiency and enthusiasm. (3) Obtain environmental approval as soon as possible. China Companies can quickly comprehend the environmental protection requirement of the host country through alliance partners, and make environmental protection certificate met the requirement. Meanwhile, China Companies can make full use of alliance partners' relationship resources to keep friendly relations with local environmental protection 
departments and groups.

Decrease Costs. First of all, decrease system cost. China Companies have the cooperation contents of MROISA enjoyed the preferential policies, which are offered by China or the host country, and develop a good relationship with related departments to obtain government approval as soon as possible.

Secondly, decrease facilities construction cost. In mining area, China Companies can build a power supply, water supply, communications and other infrastructure to meet the basic requirements of life and work, and also properly construct some auxiliary facilities to improve workers' working efficiency and life quality.

Thirdly, decrease exploration and development cost. (1) Apply Activity-Based Costing (ABC) to calculate exploration and development cost. Because ABC sharing indirect cost to activities can clearly reflect sub-job cost paid by each alliance side in the process of exploration and development, and then help to put forward the sub-job cost optimization strategy. (2) Use advanced technology, which is the fundamental way to decrease exploration and development cost. In the mineral resources exploration and development, China Companies ought to actively learn alliance partners' advanced technology and experience. If conditions permit, the development or introduction of new technology can be co-funded by both alliance sides to decrease technology acquisition cost. (3) Implement exploration and development integration. The technical and economic feasibility demonstration should be done before exploring and developing target deposit. China Companies should quickly evacuate the mining area recognized as impossible or difficult to profit, and preferentially explore and develop the mining area with strong technical and economic feasibility and high economic development value. In the process of exploration and development, if founding mineral deposit is inadmissible, China Companies ought to make feasibility demonstration again and ask alliance partners whether it conforms to the local law or experience to avoid abandoning economic deposit prematurely. For once again confirmed as qualified deposit, China Companies can speed up the working progress to shorten construction period and save cost; for once again perceived as unqualified deposit, China Companies should stop working as soon as possible to minimize unnecessary wastes.

Fourthly, decrease environmental cost. (1) Set an appropriate environmental standard for mining area. If only from a cost perspective, environmental standard can just meet the minimum requirement of the host country; if considering increasing the possibility of further cooperation between both alliance sides and reducing the resistance from local environmentalist as far as possible, China Companies can appropriately improve environmental standard. (2) Combine development with governance. Before developing, the environmental protection of mining area should be contained in the overall planning of mineral resources development to balance mineral resources demand and environmental comprehensive management, realizing organic coordination and relative balance of economic benefits and environmental benefits. Meanwhile, with the help of alliance partners, China Companies can know the environmental factor of mining area, and then forecast the environmental problem resulted from development and take effective preventive measure. In developing mineral resources, China Companies implement environmental supervision, understanding the current situation and developing trend of environmental quality. It helps to discover and deal with environmental problem quickly, and provides scientific reference for environmental management and pollutant source control.

Fifthly, decrease transport cost. Alliance partners with good traffic conditions are preferred. If the traffic isn't convenient, China Companies need to construct necessary transportation with alliance partners. When choosing the transit route of mineral resources, China Companies should keep abreast of latest information about the factors affecting transportation and take full account of these factors, and synthetically consider tangible and intangible transportation cost. If necessary, transport services can be outsourced to a professional international logistics company.

\section{The Improving Tactics of Non-expected Performance}

Accelerate Inventory Turnover and Current Assets Turnover. Firstly, accelerate inventory 
turnover. The value creation activities of MROISA contain mineral resources exploration, exploitation, beneficiation, storage, transport etc.; the value creation activities of China Companies contain mineral resources restock and processing, and products production, storage, sale etc. In order to shorten inventory turnaround time, these value creation activities should be optimized or reconstructed for their seamless connection.

Secondly, accelerate current assets turnover. In negotiation, according to the fact that foreign companies generally attach great importance to management right, China Companies can let alliance partners increase investment in exchange for alliance management right. But in order to maintain own minority equity position, China Companies can supervise and control alliance through other means. For example, major issues should be approved by a majority of special votes. Meanwhile, China Companies can grasp favorable investment opportunity with the help of alliance partners. If necessary, a professional investment institution can be hired to take responsible for investment. Because a professional investment institution can not only identify business opportunity and evaluate expected gain accurately, but also react and adjust to changing circumstances quickly, getting more incomes and reducing investment risk.

Raise Mineral Resources Utilization Rate and Product Qualification Rate. At first, raise mineral resources utilization rate. According to the characteristics of mineral resources supplied by MROISA, the applicability, operating rate, production stability, investment cost of technology, China Companies select resource utilization technology. In the process of mineral resources processing, China Companies should effectively extract target components or elements, and make comprehensive utilization of paragenetic and associated components or elements to reduce the number of tailings and pollutants.

Then, raise product qualification rate. Based on the consistent mineral resources supply of MROISA, China Companies can optimize manufacturing process to reduce nonconforming product, and also establish TQM system and apply effective methods and tools to control and manage quality in all aspects.

Increase Market Share and Enhance Market Power. Firstly, increase market share. (1) Stabilize existing customers. Through kinds of propagandizing ways, China Companies make existing customers know that companies have the ability to provide flexible, cost-effective product with the consistent mineral resources supply of MROISA, promoting them to purchase product continuously and win their trust. (2) Strive for new customers. China Companies can offer excellent after-sales service to old customers to improve their satisfied degree, which helps to build a good reputation and attract new customers. Meanwhile, China Companies can consider selling product back to the host country. When selling product, China Companies make full use of alliance partners' knowledge resources and relationship resources in local market to increase sales quantity and amount. If necessary, China Companies can improve existing product or develop new product according to local customer demand.

Secondly, enhance market power. (1) Strengthen the influence of mineral resources supply guarantee of MROISA. When building alliance, both alliance sides need to sign as complete alliance agreement as possible, which must clearly define the rights and obligations of both alliance sides, alliance management system, alliance value allocation etc. In the operation of MROISA, alliance agreement can be adjusted according to the actual situation of union sides. In order to gain as many interests as possible when adjusting alliance agreement, China Companies should strengthen their bargaining power. And the mineral resources regulators of MROISA can be established to supervise both alliance sides to invest resources in accordance with alliance agreement, coordinate the conflict and contradiction between both alliance sides, evaluate and distribute alliance value, ensure the supply of mineral resources to meet the companies' requirements etc. (2) Reinforce the influence of product. On the basic of the consistent mineral resources supply of MROISA, combining with technology and market demand, China Companies can increase product flexibility (including production flexibility, delivery flexibility and combined flexibility) to intensify product advantages, make the deep processing of existing product to increase added value, accelerate the development of new product to grasp market opportunity. 


\section{Summary}

We find that China Companies' MROISA performance is a dynamic combination of the expected-performance and non-expected performance, which has practical significance and application value to its study. Through using the presented evaluation index system and evaluation methods, China Companies can evaluate their MROISA performance and determine its size. Then according to the specific circumstances of evaluation results, through choosing the presented improving tactics, China Companies can improve their MROISA performance effectively. The innovation of this paper is that analysis the generating mechanism of China Companies' MROISA performance from the perspective of value creation, and build an evaluation index system of China Companies' MROISA performance from two aspects of the expected performance and non-expected performance. Based on the evaluation index system, we point out that the improving tactics of China Companies' MROISA performance. The deficiency is not able to make empirical test on the established evaluation index system of MROISA, which is the next research topic.

\section{Acknowledgement}

The project supported by National Natural Science Foundation of China (NSFC No. 71262030).

\section{References}

[1] Glaister K W, Buckley P J. Measures of Performance in UK International Alliances, J. Organization Studies. 19 (1998) 89-118.

[2] Nielsen B B. Determining International Strategic Alliance Performance: A Multidimensional Approach, J. International Business Review. 16 (2007) 337-361.

[3] Mohr A T. A Multiple Constituency Approach to IJV Performance Measurement, J. Journal of World Business. 41 (2006) 247-260.

[4] XIANG Gang. The Evaluation of Technology Innovation Strategy Alliance Performance, J. Technoeconomics \& Management Research. 12 (2012) 27-30.

[5] REN Hui. The Evaluation Dimensions of Knowledge Alliance Performance: A Perspective of the Comparative Analysis of Strategic Alliance, J. Journal of Information. 7 (2011) 104-108.

[6] SHI Shu-ling. The Construction of Knowledge Alliances Performance Evaluation Models Based on Different Subjects, J. Science \& Technology Progress and Policy. 18 (2011) 119-122.

[7] Mohr L. and Spekman R. Characteristics of Partnership success: partnership attributes, communication behavior, and conflict resolution techniques, J. Strategic Management Journal 15(1994) 135-152.

[8] Sampson R C. The cost of misaligned governance in R\&D alliances, J. Journal of Law, Economics and Organization. 20 (2004) 484-526.

[9] ZHANG Yan-feng, Tian Zeng-rui. An Empirical Study about the Influence of Trust and Control between Partners in Strategic Alliance Performance, J. R\&D MANAGEMENT. 6 (2007) 63-68.

[10] LIANG Jian-ying. The Influence of Different Control Modes for Alliance Performance, J. Industrial Technology Economics. 1 (2010) 57-60.

[11] LI Jian, JIN Zhan-ming. The Alliance Partner Selection, Coopetition and Alliance Performance, J. Science of Science and Management of Science \& Technology. 11(2007) 161-166.

[12] Lusch, R. F. and Brown, J. R. Interdependency, Contracting, and Relational Behavior in Marketing Channels, J. The Journal of Marketing. 60(1996) 19-38.

[13] Dyer J. H. and Singh H. The relational view: Cooperative strategy and sources of 
interorganizational competitive advantage, J. Academy of Management Review. 23(1998) 660-679. [14] Holm, D. B., Eriksson, K., Johanson, J. Creating value through mutual commitment to business network relationships, J. Strategic Management Journal. 20 (1999) 467-486.

[15] Bernard L. Simonin. The Importance of Collaborative Know-How: An Empirical Test of the Learning Organization, J. Academy of Management Journal. 40(1997) 1150-1174.

[16] Kale Prashan, Dyer J.H. and Singh Harbir. Alliance Capability, Stock Market Response, and Long-Term Alliance Success: The Role of the Alliance Function, J. Strategic Management Journal. $23(2002) 747-767$.

[17] ZEHNG Sheng-hua, RUI Ming-jie, CHI Ren-yong. The Fundamental Framework of Alliance Capability and its Mechanism of Promoting Alliance Performance, J. Science of Science and Management of Science \& Technology. 6 (2007) 22-28.

[18] PAN Si-yu. The Value Creation Effects of Chinese Enterprises' International Strategic Alliance and the Development Approaches-A Discussion Based on the International Strategic Alliance of China and ASEAN Enterprises, J. Journal of yunnan university of finance and economics. 4 (2010) 135-142. 